Table I. Grades of function before and after operation and at follow-up

\begin{tabular}{lccc}
\hline & $\begin{array}{l}\text { French window } \\
\text { laminectomy }\end{array}$ & $\begin{array}{c}\text { French window } \\
\text { laminoplasty }\end{array}$ & \\
\hline Before operation & $7.7 \pm 3.5$ & $9.2 \pm 3.1$ & NS \\
After operation & $12.6 \pm 3.3$ & $14.1 \pm 2.8$ & NS \\
At follow-up & $10.6 \pm 3.1$ & $12.9 \pm 4.5$ & NS \\
\hline
\end{tabular}

the difference was insignificant at each segment except C7. No correlation was found between the postoperative size of the epidural space and the functional grades.

The cross-sectional areas of the spinal cord were measured by metrizamide CT performed at follow-up in eight laminoplasty patients; these were compared with the sizes of the respective epidural spaces and with the functional grades. No correlation was observed between the size of the spinal cord and the epidural space, but the former demonstrated a strong correlation $(r=0.84)$ with the postoperative functional grades (Figs 1 and 2).

Conclusions. This present study has shown that French window laminoplasty was no more effective than laminectomy in preventing the postoperative development of cervical kyphosis. The postoperative narrowing of the epidural space after laminectomy was not so significant as commonly believed. Enlargement of the bony spinal canal beyond a reasonable amount had no effect on functional recovery. The key factor in determining the result was not the postoperative size of the bony canal but the ability, which the spinal cord retains, to rebound after it was relieved of compression. Laminoplasty had no significant superiority over laminectomy in the long-term results.

The authors wish to express their sincere gratitude to Miss Keiko Yasui and Miss Aiko Tsuruoka for their assistance in the preparation of this paper.

\section{REFERENCE}

Hukuda S, Mochizuki T, Ogata M, Shichikawa K, Shimomura Y. Operations for cervical spondylotic myelopathy: a comparison of the results of anterior and posterior procedures. J Bone Joint Surg $[\mathrm{Br}]$ 1985;67-B:609-15.

\title{
THE MIGRATION OF A KIRSCHNER WIRE FROM SHOULDER TO SPLEEN: BRIEF REPORT
}

\author{
F. A. POTTER, A. J. FIORINI, J. KNOX, P. B. RAJESH
}

The migration of internal fixation devices is well established. We report a case illustrating how rapidly it may occur.

Case report. A 79-year-old woman was admitted to hospital in a confused state after a fall at home. She had extensive bruising about her right shoulder and a radiograph showed a posterior dislocation. This was reduced under general anaesthesia, but the joint was found to be unstable. Two Kirschner wires, each $13 \mathrm{~cm}$ long, were therefore inserted through the humeral head into the glenoid.

Five days later the patient was noted to be dyspnoeic and she had surgical emphysema over the anterior chest wall. A radiograph showed that one of the wires was in the thorax, but there was no evidence of a

F. A. Potter, MB ChB, Senior House Officer

A. J. Fiorini, MB, MRCP, Registrar

J. Knox, MB, FRCP, Consultant

Department of Medicine for the Elderly, Kingston General Hospital, Beverley Road, Hull HU3 IUR, England.

P. B. Rajesh, MB, FRCS, Registrar

Department of Cardio-Thoracic Surgery, Castle Hill Hospital, Cottingham, North Humberside HU16 5JQ, England.

Correspondence to Dr F. A. Potter, 44 Lewisham Road, Norris Green, Liverpool LII IEF, England.

(C) 1988 British Editorial Society of Bone and Joint Surgery 0301-620X/88/2R41 $\$ 2.00$

J Bone Joint Surg [Br] 1988;70-B:326-7. pneumothorax (Fig. 1). Fluoroscopic screening appeared to show the tip of the wire pulsating within the right atrium and the patient was transferred to the cardiothoracic intensive care unit. There, her general condition



Fig. 1

precluded immediate operation and during pre-operative management, serial radiographs over two days surprisingly showed the passage of the wire into the abdominal cavity. At laparotomy the wire was found to be protruding from the costal border of the spleen. No other 
visceral damage could be identified. The wire was carefully removed but subsequent haemorrhage necessitated splenectomy. The patient made a good recovery. Discussion. The migration of Kirschner wires and other fixation devices from the shoulder region into the thorax was first reported by Mazet in 1943. Sporadic case reports have subsequently recorded remarkable journeys of wires from the shoulder region, for example, to the spinal canal (Aalders et al. 1985) and to the trachea (Kremens and Glauser 1956). Previous reports of migrations have not recorded so rapid a rate of movement of the wire as in our patient; usually it has been considered to occur over periods ranging from months (Kremens and Glauser 1956) to years (Norrell and Llewellyn 1965). The mechanism of this movement remains obscure, having been variously ascribed in the past to muscular movements, gravity and capillary action. Migration may be prevented by bending the free end of the wire, as recommended by Fowler (1981).

\section{REFERENCES}

Aalders GJ, van Vroonhoven TJMV, van der Werken C, Wijfiels CCSM. An exceptional case of pneumothorax - 'a new adventure of the $K$ wire'. Injury 1985;16:564-5.

Fowler AW. Correspondence. Injury $1981 ; 13: 261-2$.

Kremens V, Glanser F. Unusual sequelae following pinning of medial clavicular fracture. Am J Roentgenol 1956;76:1066-9.

Mazet RJ Jr. Migration of a Kirschner wire from the shoulder region into the lung: report of two cases. $J$ Bone Joint Surg $1943 ; 25: 477-83$.

Norrell H Jr, Llewellyn RC. Migration of a threaded Steinmann pin from an acromioclavicular joint into the spinal canal: a case report. J Bone Joint Surg [Am] 1965;47-A : 1024-6.

\title{
THE DIMPLE SIGN OF A RUPTURED LATERAL LIGAMENT OF THE ANKLE: BRIEF REPORT
}

\author{
A. JAFFER ARADI, J. WONG, M. WALSH
}

The treatment of rupture of the lateral collateral ligament of the ankle is still controversial (Evans, Hardcastle and Frenyo 1984). Bruising and ankle instability (Broström 1965; Hughes 1942; Lindstrand 1976) are the only clinical guides to diagnosis. In this report we describe a new sign which, when present, is highly suggestive of the condition.

Materials and methods. At the Mater Misericordae Hospital, Dublin, between November 1985 and June 1986,70 patients under the age of 40 with suspected rupture of the lateral ligament of the ankle following inversion injury had stress radiographs; surgical repair was performed if these confirmed the diagnosis.

Results. Twenty patients were clinically and radiologically stable; they were treated conservatively. The remaining 50 patients had unstable ankles and were treated surgically. In 43 of these, who were examined under anaesthesia within 48 hours of injury, a dimple appeared at the anterolateral joint line when posteroanterior stress was applied (Fig. 1), and disappeared on removing the stressing force; no dimple appeared with

\footnotetext{
A. Jaffer Aradi, FRCSI, FRCS Ed, FRCS Glas

Department of Surgery, Salmanyia Medical Centre, P.O. Box 12 Bahrain, Arabian Gulf.

J. Wong, FRCSI

M. Walsh, MCh, FRCSI

St Mary's Orthopaedic Hospital, Cappagh Road, Finglas, Dublin 11 Eire.

Correspondence to Mr A. J. Aradi.

(C) 1988 British Editorial Society of Bone and Joint Surgery $0301-620 \mathrm{X} / 88 / 2 \mathrm{R} 51 \$ 2.00$

J Bone Joint Surg [Br] 1988;70-B:327-8.
}

inversion stress. At operation it was found that the extent of the tear of capsule and ligament was directly proportional to the diameter and depth of the dimple. The remaining seven of the 50 unstable ankles were not examined under anaesthesia until seven to 10 days after injury; in them no dimple was seen on applying posteroanterior stress.

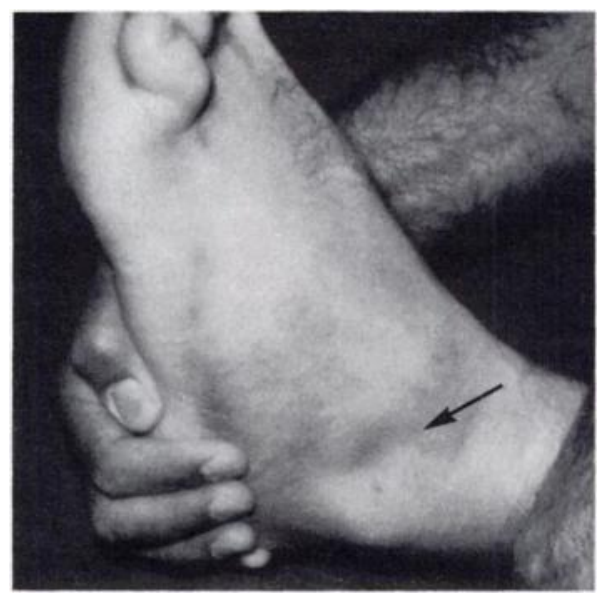

Fig. 1

Explanation of the sign. In the intact joint, posteroanterior stress is resisted by the anterior capsule and the anterior talo-fibular ligament. If these are torn the physiological joint space extends to the subcutaneous tissues; a postero-anterior stress will then displace the talus forwards, increasing the volume of the joint space still more. Applying Boyle's Law, a negative intra- 